\title{
UNNECESSARY DIFFICULTIES OF PROOF
}

\author{
MANFred W. EHRICH
}

We of the legal profession have grown so accustomed to the technical difficulties of proof that we are prone to accept the existing rules without question, overlooking the hardship and injustice which sometimes results, seldom pausing to consider whether the burdens which we are forced to assume constitute necessary or even effective safeguards against fraud or mistake.

It is not the function of the courts to establish office systems or forms for the conduct of business; their true function is to apply principles of justice to commercial transactions as habitually carried on. The courts must mold the rules of evidence to fit business practice, for they cannot expect business carried on by men untrained in the law to be conducted in the technical spirit of the courtroom. ${ }^{2}$ Only an infinitesimally small proportion of business transactions are ever drawn into litigation, and it would further neither the prosperity nor the morals of the community to have all business craftily conducted upon the assumption that the facts may some day have to be established in a court of law.

It is true that legal decisions must be based on evidence and not upon mere suspicion or conjecture. If, however, transactions as habitually .carried on in the business world cannot readily be proved in court, our judicial system must be deemed a failure.

Rules of evidence are only rules of guidance for ascertaining the truth. The truth, however, cannot be ascertained without due consideration being given to every circumstance which has or may have a substantial bearing upon the issues. Relevant evidence must not be excluded unless it is really untrustworthy. If it is genuine in all probability it should not be rejected because of a remote possibility of error. Many of the safeguards which are logical enough from an academic

${ }^{1}$ An extreme example of judicial dictation may be found in the former rule of the New York courts, now fortunately abandoned, that where the plaintiff and the defendant contradict each other on a vital issue and neither is corroborated or discredited, the plaintiff does not sustain the burden of proof and his complaint must be dismissed. Syms v. Vyse (1886, Sup. Ct.) 2 N. Y. St. Rep. 106; Losee v. Morey (1865, N. Y.) 57 Barb. 56I ; Campbell Printing Co. v. Yorkston (I895, C. P.) II Misc. 340,32 N. Y. Supp. 263; Marinelli v. Ferrand (1896, Sup. Ct.) I7 Misc. 373, 40 N. Y. Supp. I5I; Taylor, Jr. v. Ballard \& Millard (I888, Sup. Ct.) I7 N. Y. St. Rep. 598; Felbel v. Kahn (I898) 29 App. Div. 270, 5r N. Y. Supp. 435. A very large proportion of business transactions are carried on man to man, without witnesses or confirmatory writings. The courts, when applying this rule, presumably did not realize that in practical effect they ruled all such transactions to be invalid, or at least unenforceable, in any case in which the opposite party had the effrontery to deny the facts.

${ }^{2}$ Cf. 3 Wigmore, Evidence (rg04) sec. 2r55. 
point of view often lead in practice to the exclusion of genuine evidence because of the death or disappearance of witnesses or because of the difficulty, delay or expense involved in following the prescribed methods of proof. If any such supposed safeguards are unnecessary or ineffective, they should be abandoned.

Proof of Delfvery. A common example of unreasonable difficulty of proof that will occur to every practitioner is the familiar bugaboo of proving manufacture and delivery. ${ }^{3}$ When business was local in character and conducted on a small scale, it was no doubt a simple matter to call the clerk who made up the bundles, and the teamster who made delivery, and to trace the goods directly to the consignee. ${ }^{4}$

In a modern establishment, with its complicated systems of counters, checkers, stock-room clerks, packers, shipping clerks, porters, bill clerks, bookkeepers, and drivers, the matter of proving delivery is generally a burden too heavy to be borne unless a very large sum of money is involved. The question of delivery is rarely at issue. The purchaser knows quite well that a delivery was made, and, if no other issue were involved, he would pay without question. Often, however, he can, without actually committing perjury, raise the issue of delivery by a denial of knowledge, and thus force an unjust settlement upon the plaintiff, or even defeat his action.

Some years ago the writer's firm brought suit for the purchase price of some 375,000 booklets, delivered at the purchaser's direction, in comparatively small lots, to a great number of different persons. A quarrel had arisen between the defendant and its agent, who had placed the contract for the booklets and directed their delivery, and the defendant refused payment only to embarrass the agent. There was no doubt in anyone's mind that the plaintiff had performed its contract. The only real question was whether the agent had exceeded his authority. The defendant's counsel, acting within his rights, and believing that the technical proof of delivery could not be prepared in time to try the case when called on the special calendar, refused to sign a stipulation admitting delivery. The delay which would have resulted from sending the case back to the general calendar might have ruined the plaintiff. One of the writer's partners devoted practically his entire time over a period of two weeks to preparing proof of delivery. When defendant's counsel found the courtroom filled with witnesses, and the plaintiff actually ready to proceed, he promptly conceded delivery.

In another case the writer's firm represented a plaintiff suing upon a guaranty. Though the defendant guarantors were officers of the

'Lance v. Pearce, et al. (I885) Ior Ind. 595; see Hoffman House v. Hoffman House Café (1899) 36 App. Div. 176, 55 N. Y. Supp. 763; Dickerson v. Sparks. (1855) ı7 Ill. 178; Gress Co. v. Berry Bros. Itd. (I907) 2 Ga. App. 207, 58 S. E. 384 .

- But that even under such conditions it is sometimes impossible to sustain the burden of the detailed proof required, see Dinsmore v. Butler (1906, Sup. Ct.) 98 N. Y. Supp. 835 . 
vendee corporation, which had admitted delivery and given notes for the purchase price, the defendants' counsel, believing that the plaintiff could not prove manufacture or delivery, made the usual denial of knowledge. The plaintiff was forced to seek out a score of former employees of its abandoned New Jersey factory, and to produce a number of employees of its Pennsylvania factory, and to consume more than two days of the trial in proving what everyone knew to be the fact. In the course of the trial the defendants' counsel discovered that one order out of more than a hundred had been manufactured at the plaintiff's Kentucky factory. The plaintiff abandoned its claim for this item, amounting to some six or seven hundred dollars, rather than bring the necessary witnesses from Kentucky.

The testimony of most of the witnesses in these cases is purely formal. The system of counting, packing, and shipping the merchandise having been explained, the other witnesses merely testify that they performed their duties correctly to the best of their ability on this, as on all other occasions. Checkers, bill clerks, bookkeepers, porters, and shipping clerks practically always perform their routine duties correctly to the best of their abilities. If they fail, they certainly do not admit it. If some of the necessary witnesses are dead or cannot be found, the plaintiff's just claim may well be defeated. Fortunately the proof is generally so complicated that there is little chance of the defendant's counsel perceiving an occasional lapse.

It is most unjust to compel the plaintiff to disrupt its organization during the period of a trial in order to prove a fact about which there is really no dispute. The very complexity of a modern organization makes falsification of its books a practical impossibility, for a concern which falsified its books would put itself at the mercy of a myriad of employees. The employees generally have nothing to gain by making dishonest records and certainly would have no inclination to proclaim their dishonesty when called to the witness stand.

It would be entirely safe to permit books of account in evidence as proof of manufacture and delivery upon an explanation by an office manager or other person in authority of the system followed by the proponent, if, under the system as proved, the entries in question were made only if and when the goods were actually manufactured or duly shipped as the case may be. ${ }^{5}$ It should not be required that the propo-

${ }^{8}$ Cf. Clifford v. Gienger (1898) II Colo. App. 83, 52 Pac. 223; M'Clure \& Elder v. Byrd ( 1808 ) 2 Tenn. 21 (the admission of account books in this case may be explained on a different theory). In Higgs $v$. Shehee (1852) 4 Fla. 382 , the admissibility of books of account for any such purpose as advocated in the text is denied, and any rule looking to their admissibility vigorously condemned.

In Pennsylvania books of account seem to be permitted in evidence to prove delivery in a limited class of cases. Stuckslager $v$. Neel (I888) I23 Pa. 53, I6 Atl. 94; Hall v. Woolen Co. (1898) I87 Pa. 18, 40 Atl. 986; Lonergan v. Whitehead (1840, Pa.) Io Watts, 249; Nickle v. Baldwin (1842, Pa.) 4 W. \& S. 290. 
nent call each employee who had or may possibly have had some hand in the matter. ${ }^{8}$

In the above discussion we have considered only the proof of what takes place inside of the factory. Actually, however, the plaintiff does not complete his proof when he traces the merchandise out through the factory doors. If the terms of the contract are such that delivery to the carrier is a delivery to the purchaser, and the factory is located on a railroad siding or the goods are delivered by a truck owned and operated by the plaintiff, the additional burden is not a heavy one. If the plaintiff employs an independent drayman or messenger company to deliver the goods either to the purchaser or to the railroad company, it is not always easy to locate the particular driver or messenger who made each separate delivery, and the burden is sometimes insuperable.

There is some authority for a rule that delivery to a common carrier is prima facie evidence of delivery to the consignee. ${ }^{7}$ This should be the law, but it is not clearly established. The interests of justice would be adequately safeguarded by a rule that a delivery to a common carrier, private drayman, or messenger-that is, to any bailee for hire-of packages properly addressed to the consignee is prima facie evidence of delivery.

As already stated, the question of delivery is generally not really in issue. If the defendant really contends that the goods were not received, the consignee can always testify to that fact. In such a case it would be necessary in practice for the plaintiff to trace the goods to the consignee's door, for a jury would not find for the plaintiff in face of a positive denial on the witness stand that the goods were received, unless the carrier were called and delivery actually and convincingly proved.

MAILING LetTERs. In ordinary business practice letters are signed

\footnotetext{
- Books of account are admissible in evidence only after testimony of the clerks who made the entries, to the effect that they were accurately made, and were made as part of their respective duties, is offered. Shmargon v. Rosenstein (Ig20) 192 App. Div. 143, 145, I82 N. Y. Supp. 343, 344

Where the entries were made from temporary memoranda, testimony that the temporary memoranda were correctly made in the first instance, and were correctly reported to the clerks making the entries in the account books, must first be offered. Mayor, etc., of N. Y. v. 2d Ave. Ry. (I886) I02 N. Y. 572, 7 N. E. 905 ; Cobb et al. v. Wells (1891) I24 N. Y. 77, 26 N. E. 284; Rathborne v. Hatch (1904) 90 App. Div. 15I, 85 N. Y. Supp. 775.

According to some authorities, the production of the employees who made the entries upon the temporary memoranda is not essential, nor is the production of the temporary memoranda required. 3 Jones, Evidence (I9I3) sec. 569, at p. 708 ; 2 Wigmore, op. cit. supra note 2, sec. I530, at p. 1895; Wisconsin Steel Co. $v$. Maryland Steel Co. (I913, C. C. A. 7th) 203 Fed. 403; Givens v. Pierson's Adm'x. (1916) I67 Ky. 574, I8I S. W. 324; Indianapolis Outfitting Co. v. Cheyne Electric Co. (I9I3) 52 Ind. App. 153, 10a N. E. 468; West Virginia Architects v. Stewart (I9II) $68 \mathrm{~W}$. Va. 506, 70 S. E. II3.

${ }^{7}$ Bacon ข. Johnson (I885) 56 Mich. I82, 22 N. W. 276.
} 
and placed in a basket on the writer's desk, from which they are taken by a secretary and then mailed by an office boy.

The law requires that, before the letter can be admitted in evidence, it must be traced to the mail chute, letter box, or post office. ${ }^{8}$ The sender must call the secretary whose duty it was to take the letter from his desk and the office boy who stamped and mailed it and have them testify that they performed their duties on that day as on every other. ${ }^{8}$ If the secretary and office boy are still in the employ of the sender, and the office is in the vicinity of the court house, the matter is merely tedious and stupid. Actually, however, lawsuits are not generally anticipated. When they do arise they often involve transactions dating back for many years. Office boys come and go, and touch with them is quickly lost. Sometimes the materiality of a particular document becomes evident only in the course of the trial. Of course the secretary and office boy, if available, will testify that as far as they remember they performed their duties on the particular day as on every other day. Presumably the letter was mailed. If it was mislaid by reason of oversight, neither the secretary nor the office boy would be aware of it. If one of them suppressed the letter deliberately and fraudulently, he would, no doubt, hide his guilt. If the letter was written only to make a record and then deliberately suppressed, that purpose could easily be accomplished without the secretary or office boy being aware of the fact.

The demands of justice would be entirely met by admitting letters in evidence upon proof that they were signed and so placed that accord-

When a letter is shown to have been placed in the hands of the postal authorities, that is, duly stamped, addressed and mailed, a presumption of receipt arises. Oregon Steamship Co. v. Otis (I885) I00 N. Y. 446,3 N. E. 485 .

- Where a letter was shown to have been signed, sealed and stamped, and put in the office mail basket, it was nevertheless excluded for failure to call the clerk whose duty it was to drop such letters in the post office box. Gardam \& Sons v: Batterson (I910) I98 N. Y. I75, 9r N. E. 37I; see also Royle Mining Co. v. Fidelity \& Casualty Co. (Igrr) r6I Mo. App. I85, 197; I42 S. W. 438, 442; Commercial Cable Bldg. Co. v. McKenna (IgI8, Sup. Ct.) I7I N. Y. Supp. 409; Standard Fashion Co. v. Hennessy-Robinson Co. (IgII) 143 App. Div. 248, I28 N. Y. Supp. 22; . Steinhardt v. Bingham (1904) ga App. Div. 149, 85 N. Y. Supp. ro44, affirmed on other grounds (I905) I82 N. Y. 326, 75 N. E. 403 . In the last two cases receipt of the letters was denied.

The courts have sometimes gone to great lengths in demanding proof of stamping. So, testimony of one that he "mailed the letter" has been held insufficient because he did not say that he affixed the stamp. Bankers' Mutual Casualty Co. v. People's Bank (I907) I27 Ga. 326,56 S. E. 429. The same ruling was made where testimony was to the effect that the letter was "dropped" in the United States post office box. Welsh v. Chicago Guaranty Fund Life Soc. (I8g9) 8I Mo. App. 30, 36. However, the contrary was held in the well reasoned case of Oregon Steantship Co. v. Otis, supra note 8. Accord: City of Omaha v. Yancey (I9I2) gr Neb. 26r, I35 N. W. ro44; Brooks, Boardman \& Ford v. Day (I860) II Iowa, 46. 
ing to the system shown to be in use, they would have been mailed in the usual course. The requirement that the secretary and office boy should be called does not safeguard the addressee, and may, in some cases, result in a miscarriage of justice. Generally, the adversary does not really question the mailing of the letter, but puts the sender to the proof only to embarrass him, or in the hope of gaining an unjust advantage.

Telephone Conversations. Many important transactions are carried on by telephone, and the unnecessary exclusion of evidence of such transactions leads to injustice and puts a premium on dishonesty. A telephone conversation is, of course; admitted in evidence if the identity of the person at the other end of the wire is established. Evidence that the witness recognized the voice of the other party always makes the testimony admissible. Some jurisdictions have adopted a liberal rule that, where a witness asks for the telephone number of a person's usual place of business and asks for him, and someone comes to the telephone and either states, or implies by his conversation, that he is the person asked for, a prima facie case of identity is established.10 This is sound in reason and should be followed in all jurisdictions. If the witness, having called for a number, were given the wrong number, he would surely discover this in the course of the conversation. If the wrong person were called to the telephone, that would generally be discovered. The requirement that the voice be recognized is an absurdity insisted upon in the interests of mere logic and not of truth. ${ }^{11}$ It is only where the parties are well acquainted, or the voice is very characteristic, that it is actually recognized. Certainly a party testifying to a telephone conversation which took place some years before the trial, the importance of which was not then realized, cannot remember whether he did or did not recognize the voice. Frequently the parties have never met face to face, and have never conversed except over the telephone, in which case there is no basis for an identi-

${ }^{10}$ Union Constr. Co. v. Western Union Tel. Co. (1912) 163 Calif. 298, 125 Pac. 242; Wolfe v. Missouri Pac. Ry. (1888) 97 Mo. 473; Theisen v. Detroit Taxicab \& Transfer Co. (1918) 200 Mich. 136, I66 N. W. gor; Godair v. Ham Nat. Bank (1907) 225 Ill. 572, 8o N. E. 407; R. I. \& P. Ry. v. Potter (1889) 36 Ill. App. 590; Globe Printing Co.v. Stahl (1886) 23 Mo. App. 45I ; cf. Orlando v. Great Eastern Casualty Co. (I9I5) 9I Misc. 539, I55 N. Y. Supp. 20; Barrett v. Magner (I908) I05 Minn. II8, II7 N. W. 245.

${ }^{11}$ It is insisted on in New York, in spite of dicta to the effect that identification of the person at the other end of the wire may be gathered from the "surrounding circumstances." See Mankes v. Fishman (1914) I63 App. Div. 789, 149 N. Y. Supp. 228; Bonner Mfg. Co. v. Tannenbaum (Igr8, Sup. Ct.) I69 N. Y. Supp. 43; Murphy v. Jack et al. (1894) I42 N. Y. 215, 36 N. E. 882; Funk \& Wagualls Co. v. Bruem (1913, Sup. Ct.) I42 N. Y. Supp. 29x; Polstein v. Morse (I9r4, Sup. Ct.) I47 N. Y. Supp. 62; Wells v. Silverman (I9ro, Sup. Ct) I25 N. Y. Supp. 457; contra: Orlando v. Great Eastern Casualty Co., supra note Io. 
fication of the voice. ${ }^{12}$ Sometimes the conversation is the only one that the parties ever had.

In one case in which the parties had never met each other, the testimony was admitted on the witness's oath that he met the person in question in court on the day of the trial, and had then talked with him and recognized his voice as being the same that he had heard over the telephone a year or more before. ${ }^{13}$ The claim of recognition was absurd, but the telephone conversation was no doubt genuine. Making the admissibility of testimony depend upon evidence of this character puts a conscientious witness at a distinct disadvantage. One must look with leniency upon a witness who, in the interests of justice, stretches his conscience to overcome the limitations of judicial logic and put in evidence a perfectly genuine transaction.

There is no sound reason for excluding a telephone conversation if the witness testifies that he asked for the person in question, that some one came to the wire and stated that he was such person, and that thereupon a certain transaction took place. It is almost certain that the party at the other end of the wire was the one called for, particularly where the conversation is one which would have no interest for a stranger. If not, we must assume that some unknown person played a practical joke upon the witness. Fortunately such jokers are rare. If the person claimed to have answered the telephone contends that he did not do so, he can so testify, and the question of veracity can be left to the jury.

If it is thought that the liberal rule opens the door to dishonest witnesses, the obvious answer is that, a dishonest witness can always claim to have recognized the voice and then find some basis for his claim of recognition.

A greater difficulty arises when the witness, instead of calling the other person, was himself the person called. There is here very little evidence of identity, but, as business is habitually transacted over the telephone, it would be safe to assume, even in the absence of a recognition of the voice, that the person who called on the telephone was the person he claimed to be. ${ }^{14}$ If the telephone conversation was not

${ }^{12}$ However, in Thomas Henderson \& Co. Inc. v. Baron (IgI7, Sup. Ct.) I64 N. Y. Supp. 697 , in such a case the voice was held to be sufficiently "identified." Though not in accordance with the logic of the other decisions in this jurisdiction, the ruling is reasonable and in accordance with good sense.

${ }^{13}$ Woodruff v. Benesch (I920, Sup. Ct.) II2 Misc. 489, I82 N. Y. Supp. 880; Accord: People v. Strollo (1908) I9I N. Y. 42, 6r, 83 N. E. 573, 580; William Deering \& Co. v. Shumpik (I897) 67 Minn. 348, 69 N. W. I088.

${ }^{14}$ In Michigan the court made this distinction and, in spite of its positive stand for the prima facie rule where one called to the telephone is to be identified (Theisen v. Taxicab \& Transfer Co. supra note Io) said that identification of the voice is necessary where the person calling is to be identified. Miller $v$. Kelly (I92I) 215 Mich. 254, 183 N. W. 7I7. It should be noticed that the witness in this case was a third party who "listened in" on the conversation, but the case is, nevertheless, discussed as if the witness were the person called by the one to be identified. For a holding contrary to this case, but which did not discuss the distinction, see Godair v. Ham Nat. Bank, supra note to. 
genuine, the supposed author of the message can take the stand and tell his story. If the person who is supposed to have sent the message is dead or otherwise unavailable, the jury, because of its inherent suspicion of any testimony which, from its nature, cannot be met, will ordinarily discredit the whole story, unless the conversation relates to a routine matter, or is somehow corroborated or else is made extremely probable by its context. Here again, be it remembered, a dishonest witness can always put his story upon the record by claiming that he had recognized the voice.

Authenticity of LetTers. In the hurry of modern business many letters are mailed without the signature of the responsible party. Sometimes the signature is that of a stenographer. Sometimes the name of the sender is written on the typewriter. Frequently a letter bears the legend, "Dictated by Mr. — who left the office before this letter was transcribed." This may not be good practice, but it is common practice, and such letters are and must be accepted and acted upon by the recipient.

If the stenographer who transcribed the letter can be located at the time of the trial and called as a witness, there would be comparatively little difficulty in making proof, unless she denied all recollection of the transaction, which she might easily do if she did not initial the letter. ${ }^{15}$ Very frequently the stenographer has disappeared. It is submitted that it would be entirely safe and altogether in the interests of justice to admit letters purporting to come from the supposed sender written on his letterhead. If the letter had been forged the supposed sender would have little difficulty in establishing that fact, for each typewriting machine has a peculiar individuality which is readily recognizable by experts. Of course, there is a theoretical possibility that the stenographer might have written the letter without authority, but from a practical point of view this may be disregarded. If the apparent sender of the letter really questions its authenticity, he can take the stand and tell his story to the jury.

${ }^{25}$ It is necessary to prove that the letter was correctly transcribed as dictated and the identity of the author of the letter must be shown. Southern Loan \& Trust Co. v. Benbow (I904) I35 N. C. 303, 47 S. E. 435; Thayer v. Schleyl (Igro) I37 App. Div. 166, I2I N. Y. Supp. I064; cf. Whalen v. Gleeson (1909) 81 Conn. 638, 71 Atl. 908. It frequently is the case that the signature to a letter is in typewriting or is made with a rubber stamp. For the difficulties arising from such cases see Kent v. Wadley So. Ry. (I9II) I36 Ga. 857, 72 S. E. 413; Lancaster v. Ames (I907) I03 Me. 87, 68 Atl. 533; Reynolds v. Phillips (I901) I Neb. (Unof.) II4, 95 N. W. 49I; Deep River Nat. Bank's Appeal (Ig00) 73 Conn. 341, 47 Atl. 675; Nat. Acc. Soc. v. Spiro (1897, C. C. A. 6th) 78 Fed. 774; Union Central Life Ins. Co. v. Washburn (Ig0g) I58 Ala. I69, 48 So. 475; Southern Loan \&. Trust Co. v. Benbow, supra note 15; Denby Motor Truck Co. v. Mears (I921, Tex. Civ. App.) 229 S. W. 994 Letters which are received in reply to other letters which are themselves admissible are held to require only slight proof of authenticity. Several of the cases cited, supra in this note, were decided on this ground. 
A similar question arises when the letter is that of a corporation but the suit is against an officer, who dictated but did not sign the letter, and it is claimed to be relevant to show his knowledge of some fact, or because of some admission contained therein. The initial in the lower left-hand corner ought to be prima facie evidence of the identity of the author, but there is no authority to that effect. In one case of that kind the treasurer of the corporation, who signed the letter, told the writer of this article that it was dictated by the president, who was the defendant in the action. The treasurer died before the trial. The writer traced the stenographer from New York to San Francisco and from there to Japan, and there the trail was lost. As a result an important document was excluded from consideration by the jury.

Authenticity of Telegrams. The mere receipt of a telegram does not prove its authenticity. The recipient must prove that the sender delivered the original telegram to the telegraph company. ${ }^{16}$ If the original has been destroyed by the company it is practically impossible to make such proof. ${ }^{17}$ Furthermore, the body and signature of the original telegram are generally typewritten, and the delivery to the company is made by an unidentified office boy. Even if the telegraph company produces the original it is often difficult to trace it definitely to the sender.

It is true that telegrams are customarily confirmed by mail, but this is not always so, and confirmation now generally consists of an unsigned carbon copy written either on a confirmation blank bearing the printed name of the sender, or on an ordinary telegraph blank. If the confirmation bears no handwriting it adds little to the original telegram.

From a practical viewpoint, there can be little doubt that a telegram received in the ordinary course of business is the authentic act of the purported sender. If it is not, the sender can always protect himself by his oath to that effect. ${ }^{18}$ Errors in transmission can be corrected by the testimony of the sender, unless the telegraph company acts as

${ }^{10}$ Cobbv. Glen Boom \& Lumber Co. (I905) 57 W. Va. 49, 49 S. E. 1005; Oregon Steamship Co. v. Otis, supra note 8. The original for this purpose is the one delivered to the sending station of the telegraph company. Smith v. Easton (188a) 54 Md. 138; Howley v. Whipple (1869) 48 N. H. 487 ; Oregon Steamship Co. v. Otis, supra note 8.

${ }^{27}$ In the Oregon Steamship case, supra note 8 , authenticity was established by the fact that one of the telegrams received was in an agreed cipher "which identifies it with a certainty at least equal to that of a proved handwriting." The rarity of any such state of facts emphasizes the difficulties in the ordinary case.

${ }^{18}$ The Oregon Steamship case, supra note 8, recognizes the force of this argument at p. 453,3 N. E. at p. 488: "The General Term have put great stress upon the circumstance that when on the witness stand the defendant did not dispute the authenticity of the telegrams, and thence reasoned that if improperly admitted at first, they became competent afterwards. There is much of force in the argument. ....." 
his agent, in which case he is and ought to be responsible for the message as delivered. ${ }^{19}$

Proving Copies of Documents. When a document has been destroyed and it is sought to introduce a copy, the rule is that the correctness of the copy must be proved either by the person who made it or by some one who compared it with the original. ${ }^{20}$ Ordinarily this is a simple matter, but it is not always so.

In one case which arose in the writer's practice an original document was borrowed from the custodian for inspection. The borrower gave it to his stenographer and asked her to make a copy for the files. In the course of the day the copy was brought in and the borrower noted thereon the circumstances under which it had been made, and immediately returned the original to its custodian. When the case came to trial several years later it transpired that the original had been destroyed by its custodian. Fortunately the stenographer who made the copy was located, though not without difficulty. If she had died or disappeared the copy could not have been proved.

Ordinarily the stenographer does not remember the particular matter, and can testify only that whenever she made a copy of a document she tried to do it correctly, and that she never consciously made any false copies, and that if the copy offered in evidence was made by her pursuant to instructions from her employer she intended it as a correct copy. If the stenographer is dead or cannot be found, the document cannot be offered in evidence, which, if the matter is one of substance, is a gross injustice. There is no reasonable probability that the stenographer deliberately made a false copy-certainly not unless her employer had so instructed her. If she had made a false copy she presumably would not admit it. Furthermore, if the employer wanted a false copy for dishonest purposes, it would be a very simple matter to obtain one without the copyist realizing the fraud, and she would certainly not remember anything about it if some years had elapsed befure she was called to testify.

It would be quite safe to admit a copy in evidence upon testimony that the original was given to a stenographer with instructions to make a copy, and that she later submitted the paper in question as the copy so made by her.

Proving a Document by a Copy of a Copy. The rule seems to be that the copy of a copy may be admitted in evidence if the original was not in existence, or was somehow unavailable at the time that the second

\footnotetext{
${ }^{20}$ For circumstances under which the telegraph company becomes the agent of the sender to write his message and transmit it as written, see Peycke v. Shinn (1903) 68 Neb. 343, 94 N. W. I35.

${ }^{20}$ Foweler v. Hoffman (I875) 3I Mich. 2I5; Brewster v. Countryman (1834, N. Y.) I2 Wend. 446; McGinniss v. Sawyer (I869) $63 \mathrm{~Pa}$ 259; Supreme Lodge $K$. of $P$. v. Davis (I909) 90 Ark. 264, IIg S. W. 257; cf. Wills v. M'Dole (I819) 5 N. J. L. 5 ar.
} 
copy was made. ${ }^{21}$ If the original was available at the time that the second copy was made it may not be admitted in evidence, though at the time of the trial both the original and the first copy have been destroyed.

A rule such as this might be reasonable if a lawsuit were contemplated at the time that the second copy was made. Fortunately the business community does not habitually act in anticipation of lawsuits. Papers are frequently copied, not for the purposes of litigation, but for use as office records. It may not be convenient to copy the original. It may be on file in a public office, or locked in a safe deposit box, or in the hands of a third party, or in some distant state. If a copy is available and a further copy is desired, the natural thing is to copy the copy. The possibility of error is no doubt increased by the double process of copying, but the risk of resulting injustice is still negligible. The injustice of excluding material evidence because of a bare possibility of error is apparent when we consider that a witness's vague recollection of events, no matter how remote, is always admitted.

Refreshing Recollection by Copies of Documents. Assume that a subordinate in the employ of a corporation, after conducting negotiations on its behalf, submits a memorandum to his immediate superior. Assume that the superior writes to the home office embodying a copy of the memorandum in his letter. When the matter comes to trial it is found that the original memorandum has been lost or destroyed, and only the letter to the main office is in existence. It is desired to prove the negotiations in question and to have the subordinate refresh his recollection from the letter to the home office. If, after refreshing his recollection from the letter, the subordinate has an independent recollection of the events, he can testify as to that recollection, and even the original memorandum would, in such case, not be admitted in evidence. ${ }^{22}$ If, after refreshing his recollection from the letter, the witness has no independent recollection of the event, the letter to the home office would not be admissible in evidence, though the original memorandum would be admissible if in existence. ${ }^{23}$ The matter is not serious in those jurisdictions in which the witness is permitted to read from the letter

${ }^{21}$ Winn v. Patterson (I835, U. S.) 9 Pet. 663; Cameron v. Peck (1871) 37 Conn. 555. The rule is sometimes merely stated as being that "a copy of a copy will not be admitted," and it has been literally applied. Jobes v. Lower (Ig0I) 63 Kan. 886 (not reported in full), 66 Pac. 627; Carey v. Fulher (I897) 74 Miss. 729, 21 So. 752; Whitacre v. M'Ilhaney (I8I4, Va.) 4 Munf. 3Io. The rule stated in the text is, however, borne out by the better reasoned decisions.

In Stetson v. Gulliver ( 1848 ) 56 Mass. 494, it was held that any copy is admissible, the proper foundation first being made.

${ }^{22}$ Driggs v. Smith (1873) 36 N. Y. Super. Ct. 283; and see cases cited below.

${ }^{23}$ Guy v. Mead (I860) 22 N. Y. 462; Howard v. McDonough (I879) 77 N. Y. 592; Russell v. Hudson River Ry. (1858) I7 N. Y. 134; Caldwell v. Bowen (1890) 80 Mich. 382, 45 N. W. I85; Lapham v. Kelly (I862) 35 Vt. 195; Marcly v. Schults (I864) 29 N. Y. 346 ; Downs v. N. Y. Cent. Ry. (I87I) 47 N. Y. 83. 
and thus testify as to its contents. ${ }^{24}$ It is serious in most jurisdictions for there the witness is not allowed to read from the copy. If the copy gives him no independent recollection, the testimony is lost. ${ }^{25}$

A similar question arises when a witness, on returning from a conference, dictates a memorandum thereof to his stenographer. If, when the matter comes to trial, the examination of the stenographer's transcript does not give him an independent recollection of the transaction, and he cannot swear that he read the transcript at the time, the memorandum would not be admitted in evidence unless the stenographer could be found to testify that she took the dictation and transcribed it correctly according to the best of her ability. ${ }^{25 a}$ While there may be a very slight element of risk in admitting the stenographer's transcript in evidence if the witness did not examine it at the time and is unable to testify to an independent recollection, that risk is not reduced in the slightest by the testimony of the stenographer that she took the dictation and transcribed it to the best of her ability. That much can always be assumed.

Transactions with Deceased Persons. Section 347 of the New York Civil Practice Act $^{28}$ provides that a party interested in the event may not be examined as a witness against the executor or administrator of a deceased person, concerning any personal transaction or communication between the witness and the deceased person. It is very doubtful whether this prohibition furthers the interests of justice. A jury is peculiarly skeptical of any claim that cannot be met, and would ordinarily not give credence to any testimony of a transaction with a deceased person unless such testimony was directly corroborated or in some way made probable by surrounding circumstances. It is easier to meet a direct contradiction no matter how convincing, than to overcome the silent vague denial that the jury implies for the dead.

Good faith and confidence must be encouraged and unless absolutely necessary it is unfair to deprive a litigant of a just claim merely because the other party to the transaction is dead. Certainly few people realize when making an oral agreement that such agreement is subject to practical cancellation by the death of the other contracting party. If this rule against the admission of the testimony of an interested party

${ }^{24}$ See Pierce v. Bangor \& Aroostook Ry. (1900) 94 Me. I7I, I76, 47 At1. I44, I46.

${ }^{25}$ This seems to be the rule sanctioned by the weight of authority. See Caldwell v. Bowen, supra note 23; McCormick v. Pa. Central Ry. (1872) 49 N. Y. 303, 315, 316. And see I Wigmore, op. cit. supra note 2, secs. 725 , et seq. Semble: Marcly v. Schults, supra, note 23; Dozens v. N. Y. Cent. Ry., supra note 23.

${ }^{25 a}$ Quaere: Whether the memorandum may be used under such circumstances in view of the fact that it is frequently said that the witness who is to use the memorandum must be able to guarantee that the record is accurate. Russell v. Hudson River Ry., supra note 23; Guy v. Mead, supra note 23; Halsey v. Sivwsebaugh (1857) I5 N. Y. 485,488 , citing Cowen and Hill, notes to Phillips, Evidence, I Wigmore op. cit. supra note 2, sec. 747 .

${ }^{20}$ Laws, I920, ch. 925. 
concerning transactions with a deceased person is necessary to protect the community against the claims of dishonest litigants, it does not go nearly far enough, for evidence of a transaction with a deceased officer. of a corporation, or with a deceased agent, is not excluded. ${ }^{27}$ The writer has defended two such cases for corporations, and in neither case did the plaintiff meet with any success.

This article does not purport to contain an exhaustive discussion of all unnecessarily technical rules of evidence. Most of the examples cited have arisen directly or collaterally in the course of the writer's practice. They are cited as illustrative of what is believed to be a too timid and impractical attitude on the part of the courts. Every lawyer who is experienced in litigation will readily call to mind other examples of unnecessary technical difficulties-cases in which he found it necessary to perform Herculean labors in order to make formal proof of some matter which was not really open to question.

It may be well at this point to admit that the narrow rules here complained of are not always followed. Here and there an opinion may be found adopting a more liberal view. - It is also fortunately true that trial judges frequently admit evidence that may not be admissible under the strict letter of the law as found in the printed reports. Appellate courts are not bound to write opinions, and are little inclined to grant new trials when not required in the interests of substantial justice. That a more liberal view is often taken does not alter the fact that a careful advocate is compelled to prepare his cases with regard to the strict rules of evidence as found in the reports, and he cannot count on coming to trial before a bold or impatient judge. ${ }^{28}$ The liberal views occasionally found in the reported opinions or applied in unreported cases, only serve to support the plea for greater liberality made in this article.

${ }^{27}$ Hildebrant v. Crawford (I875) 65 N. Y. I07; Flaherty v. Herring-HallMarvin Safe Co. (1898, Sup. Ct.) 22 Misc. 329, 49 N. Y. Supp. 174.

${ }^{2 s}$ An illustrative experience occurred in the first year of the writer's practice. He was called in at the last moment to try for the landlord a dispossessory proceeding arising out of a failure to pay rent. The tenant had, over a period of years, failed to pay rent promptly, but he had paid odd sums from time to time, and the account was complicated. The writer advised that the correctness of the books of account must be proved, and the landlord, with rather bad grace, produced the necessary witnesses. When the first witness was called the trial judge interrupted impatiently "Don't bother with that. Offer your books in evidence." Before a decision was rendered, a tentative compromise was agreed upon. The tenant defaulted almost immediately and the same issue had to be retried in the same court before another judge a month or two later. The landlord demurred to disrupting its office for a second time, and it had good authority for saying that this was unnecessary. When the writer tried to put the books in evidence at a second trial, the judge said that they must first be authenticated and could not be admitted unless witnesses were called to prove their correctness. Only after a desperate struggle did the writer succeed in introducing the books on the faith of some very unconvincing testimony that the tenant had, shortly before the trial, admitted the books to be correct. 
It is true that difficulties of proof can generally be overcome in one way or another. Sound evidence has a way of forcing itself into the record. Counsel who make technical objections to the admission of apparently genuine evidence create an unfortunate atmosphere in the courtroom, and take great risks with the jury. If the evidence is finally admitted, the spirited objections made only serve to emphasize its effect and increase its weight. In any case a jury has confidence in the side that apparently desires to place all the evidence before them, and is prejudiced against the side that aims at concealment. Where the matter takes up a great amount of time, as for example the protracted proof of delivery, the more persistently defendant's counsel objects, the more apt is the jury to overlook the other issues and to suppose that the real contest relates to the matter which takes up the greater part of the trial.

The best lawyers dislike, both from the standpoint of decency and from the standpoint of expediency, to rely on trivial technicalities. As a result counsel frequently agree, by stipulation made in advance of the trial, that certain specified books of account, letters, telegrams, and other documents may be offered in evidence without preliminary proof, making only such reservations as may actually be necessary in the particular case. There are, however, many lawyers whose instinct impels them to rest their cases on technicalities. It is true that few good cases are defeated and few bad cases are ultimately won by such methods, but the expense and delay imposed upon the opposite party frequently constitutes a serious hardship, and often necessitates unjust compromises.

The ultimate purpose of the trial of an issue of fact is to ascertain the truth, and the truth cannot safely be determined without giving consideration to all the evidence. The mere fact that evidence may possibly be spurious, that its genuineness has not been established beyond the possibility of doubt, is not a sufficient reason for its exclusion. It is quite evident that where there is a disputed issue of fact there must necessarily be some false evidence, some testimony on one side or the other which is either deliberately perjured or unintentionally mistaken. ${ }^{29}$ The possible or even probable falsity of testimony given under oath is never considered ground for its exclusion. Though a witness called to make preliminary proof of a document be utterly discredited, the document is still admissible for what it is worth. When consideration is given to the fact that a jury does not deal with certainties, that in order to arrive at a conclusion it must always separate the wheat from the chaff, it seems unreasonable to demand that, before a copy of a document can be admitted in evidence, the proponent must exclude by direct testimony the possibility that an utterly disinterested stenographer made a false copy contrary to the instructions of her employer, or to demand

\footnotetext{
$\Rightarrow$ There are, of course, cases in which there is no dispute as to the facts, but only as to the inferences to be drawn from conceded facts. Such cases are necessarily rare.
} 
that before a telephone conversation can be considered by the jury, the possibility of the intervention of a practical joker or scheming impersonator must be negatived.

If a witness puts a telephone message in evidence by testifying that he recognized the voice at the other end, the jury gives not the slightest consideration to the claim of recognition. It knows that the witness probably could not definitely recognize the voice, and that, in any event, he would not remember at the trial whether he recognized it or not. It knows, furthermore, that if the conversation ever took place, as testified to by the witness, the person at the other end was, in all human probability, the party that he claimed to be. If this party is produced and denies that he ever had the conversation, or if he is unavailable but the genuineness of the conversation is drawn into question by counsel, the question which the jury considers is not whether one of the witnesses erred in his supposed recognition of the voice, but whether the conversation took place. The jury knows that if the witness ever had the conversation, he had it with the correct party, and that if his story is false, it is made out of whole cloth. The same is true of the other questions of evidence discussed in this article. No jury for example is interested to the slightest degree in the testimony of witnesses that as far as they can remember they performed their routine duties correctly, to the best of their ability.

If logic were to be followed to the bitter end in every case, if nothing were to be left to the imagination, there would be no end to the difficulties that might be imposed. What does it prove that a man signed a typewritten letter, unless it is shown that he was able to read, and that he read the particular letter before he signed it? What does it prove when a witness testifies that he compared a copy of a document with the original by having an assistant read the original, the witness following with the copy, unless the assistant is called to testify that he read the original correctly?

The question for consideration in each case is really one as to the probabilities. Where lies the greater possibility of injustice-in the admission or in the exclusion of the particular evidence?

Consideration must be given to the fact that the risk of injustice from the exclusion of testimony is, because of its finality, very much greater than the danger of injustice resulting from its admission. Frequently evidence is excluded although the objecting party does not really question its genuineness. $\mathrm{He}$ may be morally certain that the plaintiff's books of account are correct. Every circumstance may indicate that the goods were delivered in accordance with his instructions. He has not the slightest intention of trying to controvert the plaintiff's evidence, if once admitted. He is quite consciously striving to gain an unjust advantage from technical rules of law, and this to the full knowledge of the trial court, which, if it does not dismiss the complaint, charges the jury that the defendant is entirely within his rights in putting the 
plaintiff to the proof. Fortunately, a jury is not apt to give undue heed to this instruction, but is inclined to punish the defendant for his dishonest defense. If spurious evidence is admitted, its authenticity can generally be met by a direct denial, and the jury has an uncanny instinct for apprehending the truth in these matters. If genuine evidence is excluded from consideration in accordance with technical rules of law, that is the end of the matter.

The origin of the pervading idea that every element of genuineness must be proved by direct evidence is not quite certain. It may be a feeling that the sanctity of our procedure would be impaired if evidence were admitted without some one being subjected to prosecution for perjury in the event of its being proved false. Of all crimes, perjury is perhaps the commonest and certainly the least dangerous to the perpetrator. Hardly a sharply contested issue of fact is tried without it being made clear that the witnesses on one side or the other have been guilty of deliberate perjury. Prosecutions are rare, for prosecuting officers state that it is practically impossible to obtain a conviction without documentary proof of guilt. More probably, the imagined necessity of connecting evidence with the party against whom it is offered, by direct proof of every step arises from an over-indulgence in that consistency which Emerson calls "the hobgoblin of little minds." The reasoning seems to be that a party offering evidence must show its genuineness by direct proof ; that probabilities, however strong, inferences, however convincing, do not constitute proof ${ }^{30}$ - there must be proof, however forced, however improbable. It is no doubt easier to follow and apply rules of evidence which constitute a regular pattern. But the purpose of a trial is to achieve justice. The first essential is to arrive at the truth in reference to controverted facts. The truth cannot safely be determined if evidence which common experience indicates to be almost certainly genuine is excluded from consideration. Regular patterns are not essential. Their undue preservation is the bane of the law.

\footnotetext{
${ }^{30}$ This statement is not to be taken too literally. The courts do indulge in many presumptions. There is the presumption that one intends the natural consequences of his acts, the presumption of identity, the presumption that a letter duly mailed, or a telegram delivered to the telegraph company, is delivered in due course, the presumption that a proven state of facts continues to exist. Then also there is the presumption of the correctness of the authorities which the court may consult in determining matters of which they take judicial notice.
} 